\title{
Premature og behandlingsgrenser - etikk og prioritering
}

\author{
Utviklingen i behandlingen av ekstremt premature barn har de siste tiårene vist at vi nå nærmer oss en \\ grense der menneskelige og økonomiske kostnader synes å overstige gevinsten for de pasientene som \\ overlever med god livskvalitet. Forholdet mellom etikk og prioritering i en større medisinsk sammenheng \\ er ikke blitt lettere.
}

I en artikkel i Tidsskriftet gjennomgår Thor Willy Ruud Hansen og Reidun Førde de etiske problemstillingene som reises ved å sette en eventuelle nedre svangerskapslengde for aktiv behandling av ekstremt premature barn (1). Som i all medisinsk behandling er etiske vurderinger viktig $\mathrm{i}$ behandlingen av premature. Forfatterne hevder at man ut fra etiske vurderinger ikke kan sette en slik behandlingsgrense, fordi man ikke har behandlingsgrenser på gruppenivå for andre pasienter. Det spesielle ved ekstremt premature er at det dreier seg om individer som befinner seg ned mot eller under grensen for levedyktighet. Vår mulighet til å ha en klar vurdering av dette på forhånd er begrenset. Avansert ultralyddiagnostikk for bestemmelse av svangerskapslengde har så dårlig presisjon at det alene ikke kan brukes som grunnlag (2). Andelen barn med svangerskapslengde $22-23$ uker som gis aktiv behandling varierer derfor mellom sykehus (1). Dette er uheldig, men ulik behandling av pasienter er ikke uvanlig ved norske sykehus. Slike forskjeller har antagelig grunnleggende individuelle, medisinskbiologiske og organisatoriske årsaker.

På denne bakgrunnen er det derfor ikke riktig å gjøre forskjellen mellom palliativ og aktiv behandling til et etisk problem. Når lovgivningen i tillegg gir foreldrene et betydelig medansvar for de behandlingsvalg som gjøres, blir også foreldrenes etiske holdninger og bakgrunn viktige. De behøver ikke være de samme som behandlernes, særlig ettersom vi har et multikulturelt samfunn. Opplysninger om overlevelse og komplikasjoner ved den enkelte avdeling gir i denne sammenhengen verdifull informasjon for både helsepersonell og foreldre, men har liten relevans for den enkelte pasient. Dersom ikke all behandling av ekstremt premature skal samles ved én enkelt avdeling, må dette nødvendigvis også føre til forskjeller mellom sykehusene.

\section{Kunnskapsgrunnlaget}

Hansen \& Førde viser til at en aktiv behandlingsstrategi av selv de minste premature barna har ført til stadig bedret overlevelse. Utviklingen de siste årene har likevel vært marginal. Allerede i 1970 overlevde $43 \%$ av barn født i Norge med svangerskapslengde $<28$ uker eller fødselsvekt $<1000 \mathrm{~g}$, også barn født etter 25 uker overlevde (3). Ti år senere hadde dette økt til $48 \%$, og nå, snart 50 år senere har overlevelsen i denne gruppen økt til noe over $80 \%$ (1). I en artikkel fra USA med over 30000 barn med svangerskapslengde 22-28 uker var det ingen økt overlevelse over tid fra 1993 til 2012 for flere av svangerskapslengdene (22 uker og 26 uker) og bare marginale, men statistisk signifikante bedringer for de andre. Det var bare marginale forskjeller

\section{«Fremfor å bruke ytterligere ressurser på å utvide grenselandet, bør disse brukes på bedre kvalitet i den behandlingen vi alle- rede gir»}

på alvorlige komplikasjoner, og andelen barn som ble skrevet ut uten større morbiditet viste liten økning, bortsett fra for barn med svangerskapslengde 27 og 28 uker (4). I en tilsvarende studie der man bare undersøkte mortalitet, gikk dødeligheten i perioden 2000-11 ned fra 275 til 258 per 1000 fødte. Dette er en liten, men likevel statistisk signifikant forskjell (5).

I denne forbindelsen er det interessant at man i Nederland lenge hadde en nedre grense på 26 uker for aktiv behandling av ekstremt premature. I 2006 ble denne grensen senket til 25 uker, og nylig ble resultatene av endringen publisert (6). Selv før denne endringen hadde det vært en bedret overlevelse for alle svangerskapslengder, også for barn med svangerskapslengde under den offisielle grensen. Etter at grensen ble 25 uker, økte overlevelsen for barn født etter 24 uker og 25 uker, men morbiditeten hos overlevende gikk samtidig opp (6). Biologien hos de aller minste barna synes derfor å sette grenser som selv avansert teknologi ikke alltid kan kompensere for.

Denne skuffende utviklingen har da også medført at noen nå tenker nye veier i behandlingen av ekstremt premature barn (7). På det internasjonale møtet Hot Topics in Neonatalogy i desember 2015 ble det lagt frem foreløpige data der sterkt premature lammefostre ble forløst med keisersnitt, men fikk videreført fosterlivet og veksten gjennom intravaskulær navlesnorsernæring, omsluttet av kunstig fostervann inne i en plastsekk, såkalt ESPI-teknikk (Extracorporal Support of the Premature Infant). På denne måten klarte man å opprettholde normal fostervekst og hjerne- og lungeutvikling i flere uker. Forskerne så optimistisk på at dette innen overskuelig fremtid kunne bli aktuell behandling for ekstremt premature på 23 uker og under, barn som hadde dårlig prognose med nåværende behandling. Mitt inntrykk var at neonatologene på konferansen hadde to reaksjoner på presentasjonen, enten forferdelse eller entusiasme.

Slike forskningsprosjekter viser med all tydelighet at man med nåværende teknologi synes å ha kommet til en grense $\mathrm{i}$ behandlingen av ekstremt premature. Jeg er likevel enig $i$ at det kan være problematisk å skulle understreke dette ved å sette en absolutt grense for behandling, slik man på en måte har gjort i Nederland (6). Til det er usikkerheten i bedømmelse av både svangerskapslengde og levedyktighet for stor. Dette gjenspeiles da også i det faktum at nesten ingen nyfødte dør av sin sykdom eller medisinske tilstand, de dør fordi man velger å avslutte en behandling som har vist seg ikke lenger å ha noen hensikt (8). Erfaringene fra Nederland viser også at selv om man ut fra helsepolitiske og medisinske vurderinger anbefaler en nedre grense for å vurdere aktiv behandling, vil det i praksis si at også noen barn under grensen gis behandling.

\section{Prioritering av helseressurser} Behandling av ekstremt premature barn må også ses i relasjon til prioriteringskriteriene, noe Hansen \& Førde synes å ha glemt. Behandlingen av barn med svangerskapslengde 22-23 uker er antagelig den mest kostbare behandlingen som gis i spesialisthelsetjenesten $(9,10)$. Behandlingen av barn med fødselsvekt $<750 \mathrm{~g}$ som ved hjemreise var vurdert som frisk, kostet nesten 5,4 millioner kroner (9). For barn $<1000 \mathrm{~g}$ var kostnaden vel 3,6 millioner kroner (10). I en lederartikkel i Tidsskriftet mente man at kostnadene alene var så store at slik behand- 
ling ikke burde gis prioritet (11). Dette førte igjen til en begrenset diskusjon av dette temaet $(12-15)$. På grunn av medisinske og økonomiske grunner har utviklingen vist at det også her i landet tvinger seg frem en nasjonal prioritering med aktiv grensesetting for ulike typer behandling, f.eks. dyr kreftbehandling. Det kan ikke være riktig at én spesiell pasientgruppe skal skjermes mot denne utviklingen.

\section{De vanskelige valgene}

Hansen \& Førde illustrerer denne vanskelige prioriteringen ved å vise til at helsepersonell synes å ha en lavere terskel for å behandle alvorlig syke eldre barn eller voksne enn sterkt premature i starten av livet. Dette vurderer de som et brudd med vårt etiske ansvar. Premature er imidlertid ikke som andre pasienter. Selv om «prematuritet» er en diagnose i ICD-10, er ikke dette en sykdom, men en tilstand. Behandlingen er betydelig mer kompleks enn hos de fleste andre pasienter der sykdomsbildet kan vurderes i lys av pasientens øvrige situasjon og historie. I forhold til de fleste andre pasientgrupper vil også våre valg kunne få store og livslange konsekvenser for pasientens familie, nettverk og samfunn. Dette utgjør et viktig skille mellom denne gruppen og de fleste andre pasientgrupper. Det kan ikke være helsepersonellets etiske ansvar å behandle så ulike pasienter mest mulig likt.

\section{En farbar vei videre?}

Jeg er enig med Hansen \& Førde om at denne problemstillingen best håndteres ved at beslutningene individualiseres. Men dette må ikke bare gjelde den medisinske tilstanden til den enkelte pasient, men også gi aksept for individuelle holdninger og vurderinger fra helsepersonellets og foreldrenes side. Min enighet med forfatterne har dessuten en litt annen bakgrunn. Forfatterne tar utgangspunkt $\mathrm{i}$ at palliativ behandling vil føre til at mange barn som kunne ha overlevd med god livskvalitet blir ofret for å spare andre barn for et liv med lidelse og funksjonshemning. Jeg vil heller stille spørsmål ved om ikke en altfor aktiv behandling vil føre til at flere barn blir påført et liv med lidelse og funksjonshemning for at noen flere skal overleve med god livskvalitet. I slike forenklede problembeskrivelser blir imidlertid ikke hensynet til tredjeperson, familie og samfunn, en del av vurderingen. Ved Pediaterdagene, som nylig ble avholdt ved Oslo universitetssykehus/Akershus universitetssykehus, holdt professor John Lantos fra USA et interessant foredrag omkring disse problemstillingene. Med bakgrunn i at det sannsynligvis er noen liv som er verre enn døden, både for barnet og dets foreldre, påpekte han at det i denne debatten syntes å være for lite oppmerksomhet om «den takknemlige døde». Norsk nyfødtmedisin synes generelt å ha en balansert medisinsketisk tilnærming til disse problemstillingene. Fremfor å bruke ytterligere ressurser på å utvide grenselandet (9), bør disse brukes på bedre kvalitet i den behandlingen vi allerede gir samt på oppfølging og tilbud til de mange barn som overlever med betydelig funksjonshemning og deres familier.

\section{Dag Bratlid}

bratlid@vikenfiber.no

Dag Bratlid (f. 1944) er spesialist i pediatri, tidligere professor ved Norges teknisk-naturvitenskapelige universitet og tidligere overlege i nyfødtmedisin ved Barne- og ungdomsklinikken, St. Olavs hospital. Han har vært leder av interessegruppen for nyfødtmedisin i Barnelegeforeningen og er æresprofessor ved universitetet i Xi'an i Folkerepublikken Kina. Forfatteren har fylt ut ICMJE-skjemaet og oppgir ingen interessekonflikter.
Litteratur

1. Hansen TWH, Førde R. Premature og behandlingsgrenser. Tidsskr Nor Legeforen 2016; 136 45-7.

2. Bratlid D. Bestemmelse av fødselstermin ved tidlig ultralydundersøkelse - galt, galere, galest? Tidsskr Nor Lægeforen 1991; 111: 1379-81

3. Bratlid D, Nordermoen A. Behandlingen av svært for tidlig fødte barn de siste 40 år. Tidsskr Nor Legeforen 2010; 130: 1127-9.

4. Stoll BJ, Hansen NI, Bell EF et al. Trends in practice, morbidity, and mortality of extremely preterm neonates, 1993-2012. JAMA 2015; 314: 1039-51.

5. Patel RM, Kandefer S, Walsh MC et al. Causes and timing of death in extremely premature infants from 2000 through 2011. N Engl J Med 2015; 372: $331-40$.

6. Zegers MJ, Hukkelhoven CW, Uiterwaal CSPM et al. Changing Dutch approach and trends in short-term outcome of periviable preterms. Arch Dis Child Fetal Neonatal Ed 2016; 0: F1-6.

7. Davis RP, Bryner B, Mychaliska GB. A paradigm shift in the treatment of extreme prematurity: the artificial placenta. Curr Opin Pediatr 2014; 26 : $370-6$.

8. Syvertsen L, Bratlid D. Avslutning av behandling ved alvorlig sykdom hos nyfødte. Tidsskr Nor Lægeforen 2004: 124: 2483-5.

9. Nordermoen A. Behandlingen av ekstremt premature barn - våre dyreste pasienter? Hovedoppgave. Trondheim: Det medisinske fakultet, Norges teknisk-naturvitenskapelige universitet, 2009.

10. Nordermoen A, Bratlid D. Kostnader ved behand ling av svært for tidlig fødte barn. Tidsskr Nor Legeforen 2010; 130: 1130-4.

11. Frøisland DH. Behandlingsgrenser for ekstremt premature. Tidsskr Nor Legeforen 2010; 130: 1120

12. Hansen TW. Begrenset behandling av dyre premature? Tidsskr Nor Legeforen 2010; 130: 1447

13. Johansson KA, Miljeteig I. Rettferdig bruk av kostnadsdata. Tidsskr Nor Legeforen 2010: 130: 1448

14. Nordermoen A, Bratlid DA. Nordermoen \& D Bratlid svarer. Tidsskr Nor Legeforen 2010; 130: 1448

15. Frøisland $\mathrm{DH}$. Den vanskelige nyfødtmedisinen Tidsskr Nor Legeforen 2010; 130: 1596.

Mottatt 15.2. 2016, første revisjon innsendt 18.2 2016, godkjent 22.2. 2016. Redaktør: Ketil Slagstad.

Publisert først på nett. 